IJMS 17 (1), 129-147 (2010)

\title{
AN EMPIRICAL ANALYSIS OF THE IMPACT OF VARIOUS DIMENSIONS OF WORK-LIFE BALANCE ON ORGANISATIONAL COMMITMENT AMONG SERVICE SECTOR EMPLOYEES IN INDIA
}

\author{
RINCY V. MATHEW \\ N. PANCHANATHAM \\ Department of Business Administration \\ Annamalai University
}

\begin{abstract}
The present study examined the relationships of the various facets of work-family balance with organisational commitment $(O C)$ and its various dimensions among employees working in the service sector in India. Data were collected from 408 employees by means of questionnaires. Correlation and linear regression analysis of the collected data demonstrated that while one of the dimensions of work-life balance namely, work interferes with personal life (WIPL), acted as a significant negative predictor of $O C$, another dimension that is work enhancement/ personal enhancement $(W E / P E)$ showed significant positive impact on OC. The third dimension, personal life interferes with work (PLIW) even though showed a negative correlation; the impact was generally not significant. The article concludes with the managerial implications of the study in service sector industries/institutions.
\end{abstract}

\section{Introduction}

In India, contribution of the service sector to the national economy has been considered as an important factor in the determination of the national GDP. Its contribution toward GDP in 2006-2007 was reported to be 55\% (Shah \& Agrawal, 2008). Naturally, this sector also holds the maximum share in the job market and the trend is expected to continue in the near future also. However, it may be mentioned that due to the prevailing world economic challenges, organisations also try to reduce the expenses and keep up the percentage of profits through various management techniques including planned reductions in the product unit output, withdrawal of many of the financial and non-financial benefit to the employees including family benefit schemes, long hours of work, cutting short the holidays and even trimming down the work force. Through these initiatives, the organisations try to achieve their targets and while negotiating to reach these targets, employees are often faced with an entirely new work role with increased challenges, prestige, greater responsibilities, and pressures of many kinds. 
According to Harvey (1985), such situations in the work domain leads to stresses of varied types and creates imbalance with the family domain of the employees. This is specifically important in the case of employees having spouse and dependents and it is naturally difficult to cope with their family responsibilities in view of the greater demands from the work domain. Under such circumstances, employees find it is absolutely difficult to strike a balance between commitment to the organisation and non-work roles. Haung, Hammer, Neal, and Perrin (2004) were of the view that as the relationship between work and family are highly interdependent and dynamic; the proper integration of work and family roles is a challenge for the employees.

This is because of the infringement of the work and family domains to each others border. This concept acquires more significance in the present global state of business and economic crisis. Failure to achieve a healthy work life balance can lead to a cascade of issues which may be counter productive in the work as well as the family domains. In contrast to these types of interferences, the experience or participation in one domain may increase the quality or the performance in the other domain because the experiences gained in one domain may lead to benefits/or personality enrichment, - which in turn shall enhance the performance or involvement in the other domain. Such enhancements could also be bi-directional. That is work to family enhancement and family to work enhancement. Enhancement in work domain provides benefits such as development of skills, a change in the mood to become more positive and these will be reflected as positive effects on the family. On the other hand, enhancement in personal life results in the creation of a positive mood, feeling of support/ feeling of success, etc., which can help the individual to cope better with and discharge more efficiently and confidently his or her role at work (Sieber, 1974; Fisher, 2001; Wayne, Mussica \& Fleeson, 2002; Greenhaus \& Powell, 2006).
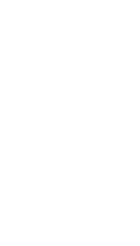

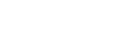

-

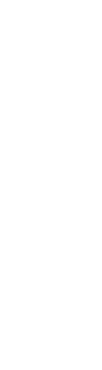

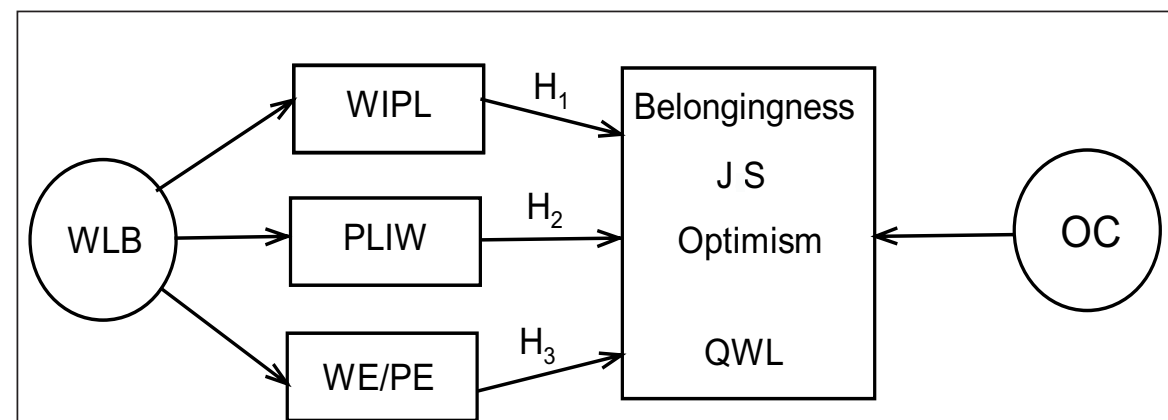

Note OC $=$ Organisational commitment; JS = Job satisfaction; PLIW = Personal life interference with work life; $\mathrm{QWL}=$ Quality of work life; WE/PE= Work/personal life enhancement; WIPL = Work life interference with personal life; WLB = Work life balance.

Figure 1. Theoretical framework of the relationship between work life balance and organisational commitment. 


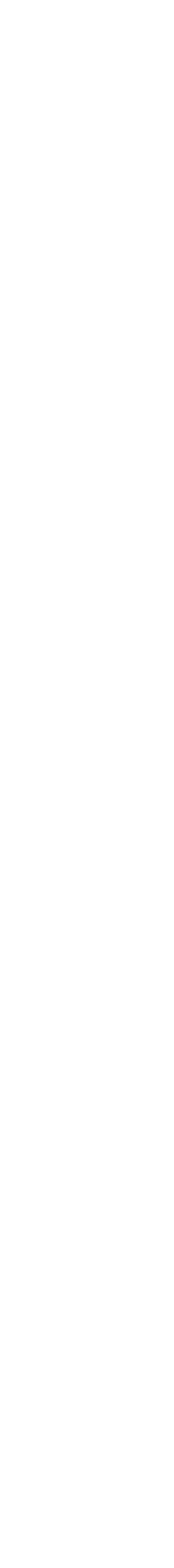

Therefore in the present economic and business scenario, the need for increased research on these issues and their impact on organisational commitment (OC) need not be over emphasised. There are some studies exploring the nature of work family conflict in the Indian context involving high technology firms, financial services, manufacturing industries, hospitality and telecommunication organisations (Aryee, Srinivas, \& Tan, 2005; Poster \& Prasad, 2003; Namasivayam \& Zao, 2007). However, studies dealing with work life balance in relation to $\mathrm{OC}$ in the Indian context, involving service sector industries, are extremely rare. Therefore, the present work is an attempt to understand work life balance and its relationship with the employee commitment to their organisations, especially in the service sector in the Indian context (Figure 1). Details regarding the respondents are provided in Table 1.

\section{Review of Literature}

\section{Work Life Balance}

While dealing with work family issues Katz and Kahn (1978) have opinioned that under conditions of especially high demands from one of the two domains (work/family), resources (psychological and behavioural) for the other domain is bound to suffer, leading to difficulty in meeting the role demands arising from that domain. In other words, if an individual is exceptionally committed to a particular domain, there is a greater chance for the inadequacy of the resources to meet the demands from the other domain so that the net outcome of such an imbalanced situation could be more severe.

Based on the human capital theory of Becker (1985; 1991), Shaffer, Harison, Gilley, and Luk (2001) formulated that employees have access to a finite pool of personal resources. In their most basic form, these resources are time (allocated to behaviours) and energy (both physical and psychological). Human capital theory argues that people prioritise broad domains of activities (for example work, family, and leisure) that they are willing to allocate resources to and then make the choices about how to spend the resources. As time and energy are exhaustible commodities, once spent they are not available for other tasks either within the same domain or other domains. Human capital theory provides an avenue for understanding the direct influence of family based inputs in combination with the work-based inputs on work life balance. From this perspective, it is clear that inter-role conflict occurs when one domain interferes with the other and in all probabilities; a struggle to maintain a balance between the two ensues. According to Greenhaus and Beutell (1985), this struggle is especially stressful when the two phases of life are of similar salience and dependent on each other for resources, as in the case of work and family.

IJMS 17 (1), 129-147 (2010) 


\section{Dimensions of Work Life Balance}

Various workers (Frone, Russel, \& Cooper, 1992; Gutek, Searle, \& Kepa, 1991; Rice, Near, \& Hunt, 1980) have studied the influences of different counteracting factors on work family issues and proposed certain common dimensions for the work life balance concept. According to them, work family imbalance could arise due to reasons originating either from work or family domains. The situation may be either work interferes with the resources allocated to the personal life (family domain) (WIPL) or personal life (family) interferes with the resources allocated to the work domain (PLIW). The origin of a third dimension of work life balance namely work/personal life enhancement (WE/PE) may be traced back to Payton-Miyazaki and Brayfield (1976). They considered work as a socialising force whereby workers learn skills, values, expectations, social philosophies, and so forth; and the workers carry over these qualities to the family. Later Zedeck (1992) and Fisher (2001) also referred WE/PE as the extent to which one's personal life is enhanced by work and vice versa.

While studying work family conflict, Greenhaus and Beutell (1985) proposed that during situations of PLIW, greater demands from family domain could utilise resources from the work domain leading to reduced performance in the work domain and the reverse effect occurs in the case of WIPL. In such situations, reallocation of resources across domains is the only probable way to combat the resources drains. Shaffer et al. (2001) have further highlighted this concept by stating that in some situations, this might be accomplished - by taking the time or energy one might have spent on recreational or community activities and pouring it into work. These types of issues are the basis for the arguments in favour of implementing work life balance practices for the employees.

On the other hand Greenhaus and Powel (2006) have considered work and family as allies under certain situations and found that they enrich each other. In such cases, experiences in one role may enhance the performance in or induce positive impacts in the other role, which was referred to as work / personal (family) life enrichment or enhancement (WE/PE) by Fisher (2001). Although work life balance is a multifaceted construct (Fisher, 2001) and its various facets are WIPL, PLIW, and WE/PE; WIPL and PLIW are closer in terms of work family conflict. But, WE/PE improve work, personel, and social satisfaction (Danes, 1998; Kinnier, Katz, \& Berry, 1991; Duncan \& Goddard, 1993). It may be concluded that work and family are interdependent domains and therefore, problems occurring in the work domain could affect family domain and vice versa. Similarly, enhancement in one domain may enrich the other also.

132 IJMS 17 (1), 129-147 (2010) 


\section{Organisational Commitment (OC)}

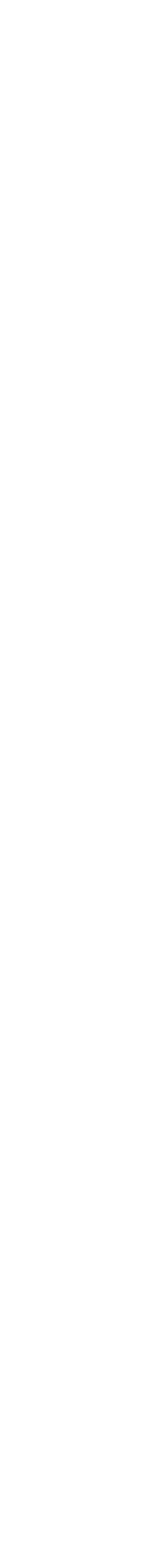

Mowday, Porter, and Stears (1982) have defined commitment as the willingness to expend personal, temporal and psychological resources on behalf of a particular domain. They further explained OC as the extent to which an individual identifies and is involved with his or her organisation and/or is unwilling to leave it. Commitment generally constitutes a variety of behaviours, cognitions, and attitudes in favour of that particular domain. In their classical studies Nauman (1993) and Tett and Mayer (1993) have considered OC also as a well-established determinant of employee withdrawal cognition. According to Meyer and Allen (1984) OC is a psychological state that characterises the employee's relationships with the organisation and has implications for the decision to continue membership in the organisation. Furthermore, Taylor, Audia, and Gupta (1996) are of the view that employees generally consider OC as an obligation toward the organisation and it is natural that the organisation expects employees to be committed in return for a range of benefits and support it renders toward them.

\section{Dimensions of Organisational Commitment}

Based on the basic concept of Mowday et al. (1982), Hyde and Roy (2006) had identified four dimensions for OC. They are belongingness, job satisfaction, optimism, and quality of work life (QWL). Hartog, Hoogh and Keegan (2007) observed more helping and compliance behaviour among employees having a strong sense of belongingness. Jones and Lathlean (2008) argued that belongingness has an intuitive appeal and since human beings are social creatures, the need to belong and be accepted are fundamental psychological needs.

According to Lok and Crawford (2004), innovative and supportive organisational culture and leadership style would induce both job satisfaction and commitment. Wright and Corpanzano (2007) had made the concept clear by defining job satisfaction as the psychological well being of the worker. They further stated that such a happy worker would have higher job performance and possibly higher job retention also.

As far as optimism (the third dimension of $O C$ ) is concerned, Segerstrom and Nes (2006) were of the view that optimists could persist upon pursuing goals and may have beneficial consequences such as protection against negative effect and greater likely hood of goal attainment. Further, Greesa, Wellmana, and Laissiterb (2009) had demonstrated that for high priority goals, optimistic individuals would indeed increase goal engagement and would be more likely to attain their goal relative to individuals low in optimism. QWL is an inseparable element of OC. However, as the voluntary dissemination of QWL practices is very much limited due to the monetary

IJMS 17 (1), 129-147 (2010) 
preferences of employers, Lawlera (1982) had suggested a number of legislative and public policy approaches to improve QWL. This view is again reinforced by Katzella (1983) by suggesting that it would be more strategic to promote programmes that improve both QWL and productivity.

\section{Research Gap}

According to Kossek and Ozeki (1998), both WIPL and PLIW are found to have a significant negative influence on job satisfaction, which is a dimension of OC. Even though it is a general assumption that employee commitment enhances performance and organisational effectiveness, investigations pertaining to $\mathrm{WE} / \mathrm{PE}$ and their relation to OC are scanty (Gudmundson, 2003). Similarly there are only a limited number of studies investigating the relationship between work, family issues (like balance or conflict), and OC (Namasivayam \& Mount, 2004; Karatepe \& Killic, 2007; Namasivayam \& Zao, 2007). Moreover, even though the service sector plays a pivotal role in India's GDP, studies correlating work life balance and OC of employees working in this sector in India are extremely rare.

\section{Hypotheses}

On the basis of the fundamentals presented above, efforts had been made in the present study to examine the positive as well as negative impacts of various dimensions of work life balance such as WIPL, PLIW, and WE/PE on $\mathrm{OC}$ and we propose the following hypotheses.

$\mathrm{H}_{1}$ : Work interference with personal life (WIPL) has a negative effect on organisational commitment and its dimensions.

$\mathrm{H}_{2}$ : Personal life interference with work (PLIW) has a negative effect on organisational commitment and its dimensions.

$\mathrm{H}_{3}$ : Work enhancement/personal life enhancement (WE/PE) has a positive effect on organisational commitment and its dimensions.

\section{Methods}

\section{Respondents}

Respondents were selected randomly from the vast population (more or less infinite) of service sector employees. All of them worked in India and they were either full or part-time employees. A total of 1062 employees were contacted for this study and 408 of them responded positively. They were 


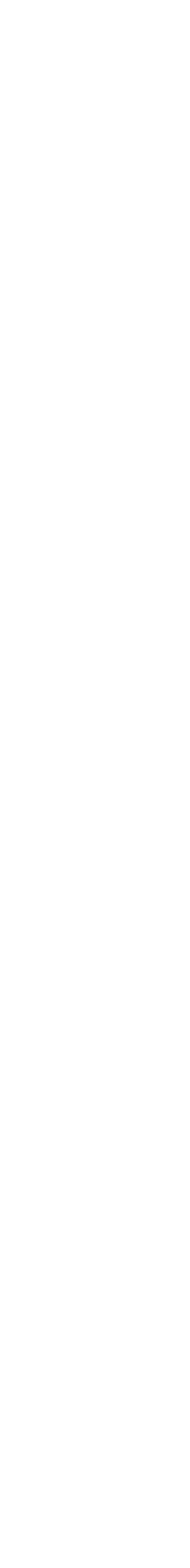

employed either in government (37.5\%) or in private sector $(62.5 \%)$, ranging from medical $(12.6 \%)$, information technology $(32.3 \%)$, academic institutions (higher education) (29.8\%), financial institutions (18.2\%), and law and order (police) department (7.1\%). Out of the 408 employees responded to this study, $61.3 \%$ were married and $38.7 \%$ were single, while $55.9 \%$ were males, $44.1 \%$ of them were females. Other demographic details such as number of dependents, age group of the respondents, etc. are given in the Table 1.

Table 1

Socio-Demographic Factors of the Respondents

\begin{tabular}{|c|c|c|c|c|c|}
\hline Category & Section & $\mathrm{f}$ & $\%$ & $\mathrm{M}$ & SD \\
\hline Sector & $\begin{array}{l}\text { Private } \\
\text { Government }\end{array}$ & $\begin{array}{l}255 \\
153\end{array}$ & $\begin{array}{l}62.5 \\
37.5\end{array}$ & 1.38 & 0.48 \\
\hline Profession & $\begin{array}{l}\text { Information technology } \\
\text { Academician (higher education) } \\
\text { Financial institution } \\
\text { Medical } \\
\text { Police Department }\end{array}$ & $\begin{array}{r}132 \\
122 \\
74 \\
51 \\
29\end{array}$ & $\begin{array}{r}32.4 \\
29.9 \\
18.1 \\
12.5 \\
7.1\end{array}$ & 2.32 & 1.24 \\
\hline Marital status & $\begin{array}{l}\text { Married } \\
\text { Single }\end{array}$ & $\begin{array}{l}250 \\
158\end{array}$ & $\begin{array}{l}61.3 \\
38.7\end{array}$ & 1.39 & 0.49 \\
\hline Gender & $\begin{array}{l}\text { Male } \\
\text { Female }\end{array}$ & $\begin{array}{l}228 \\
180\end{array}$ & $\begin{array}{l}55.9 \\
44.1\end{array}$ & 1.44 & 0.50 \\
\hline Dependents & $\begin{array}{l}\text { Nil } \\
\text { Equal/less than } 3 \\
\text { More than } 3\end{array}$ & $\begin{array}{r}2 \\
103 \\
303\end{array}$ & $\begin{array}{r}0.5 \\
25.2 \\
74.3\end{array}$ & 2.73 & 0.45 \\
\hline Age & $\begin{array}{l}\text { Up to } 30 \\
31 \text { to } 40 \\
\text { Above } 40\end{array}$ & $\begin{array}{r}68 \\
167 \\
173\end{array}$ & $\begin{array}{l}16.7 \\
40.9 \\
42.4\end{array}$ & 2.25 & 0.73 \\
\hline
\end{tabular}

\section{Procedures}

The envelope containing questionnaires were either handed over directly or mailed to the employees working in various service sector organisations in India. In addition to the questionnaires, the envelopes included a cover letter, a demographic data sheet, and a stamped self-addressed envelope for reply. The cover letter clearly explained the aim of the study with an assurance to treat their personal data as confidential. In the demographic data sheet, name of the employee and organisation (not category/sector) were made optional and surprisingly, the majority of the respondents opted not to disclose these details. Completed questionnaires were received either directly or by mail. Of the 1062 questionnaires distributed only 408 were returned. The rate of reply was $38.42 \%$. 


\section{Measures}

\section{Work Life Balance}

Fisher's (2001) work-life balance questionnaire was used to tap the respondent's opinion about their work-life situation. It consisted of three dimensions, namely WIPL, PLIW, and WE/PE. Respondents were given a set of 16 statements concerning their experience in work and family domains. They rated each item on a five-point scale ( $5=$ Never to $1=$ Very Often) to determine the extent to which it was true for their experience. Twelve items were negatively worded and scores for these items were reversed prior to analysis. Fisher (2001) had reported internal consistency reliability values of 0.89 for WIPL, 0.82 for PLIW, and 0.75 for WE/PE respectively. In the present study the scale reliability for work life balance was 0.78 .

\section{Organisational Commitment}

A 30-item scale developed by Hyde and Roy (2006) was used for measuring organisational commitment. The scale consisted of dimensions, namely belongingness, job satisfaction, optimism, and quality of work life (QWL). Each item in the scale was scored on a five-point scale (5 for Strongly Agree to 1 for Strongly Disagree). The individuals with high scores indicated that they were highly committed to the organisation. The reported internal consistency reliability values of belongingness, job satisfaction, optimism, and QWL were $0.65,0.73,0.56$, and 0.65 respectively. In the present study the scale reliability for organisational commitment was 0.66 .

\section{Results}

The correlation matrix (Table 2) shows means, S.D., and the associations among the various dimensions of work-life balance and organisational commitment of the various service sector employees who responded to the present investigation. WIPL showed a significant $(p<0.01)$ positive - correlation with PLIW $(\mathrm{r}=0.989)$. On the other hand it showed significant $(\mathrm{p}<0.01)$ negative correlations with the feeling of belongingness toward the organisation $(r=-0.502)$, job satisfaction $(r=-0.453)$, optimism $(r=-0.622)$, QWL $(r=-0.459)$, and OC $(r=-0.502)$ of the employees; while PLIW showed significant $(\mathrm{p}<0.01)$ negative associations with belongingness $(\mathrm{r}=-0.488)$, job satisfaction $(\mathrm{r}=-0.436)$, optimism $(\mathrm{r}=-0.618)$, QWL $(\mathrm{r}=-0.448)$, and OC $(r=-0.488)$; WE/PE exhibited significant $(\mathrm{p}<0.01)$ positive correlations with belongingness toward the organisation $(r=0.743)$, job satisfaction $(r=0.786)$, optimism $(\mathrm{r}=0.595)$, QWL $(\mathrm{r}=0.762)$, and OC $(\mathrm{r}=0.743)$. Other significant correlations between various factors are given in Table 2 . 


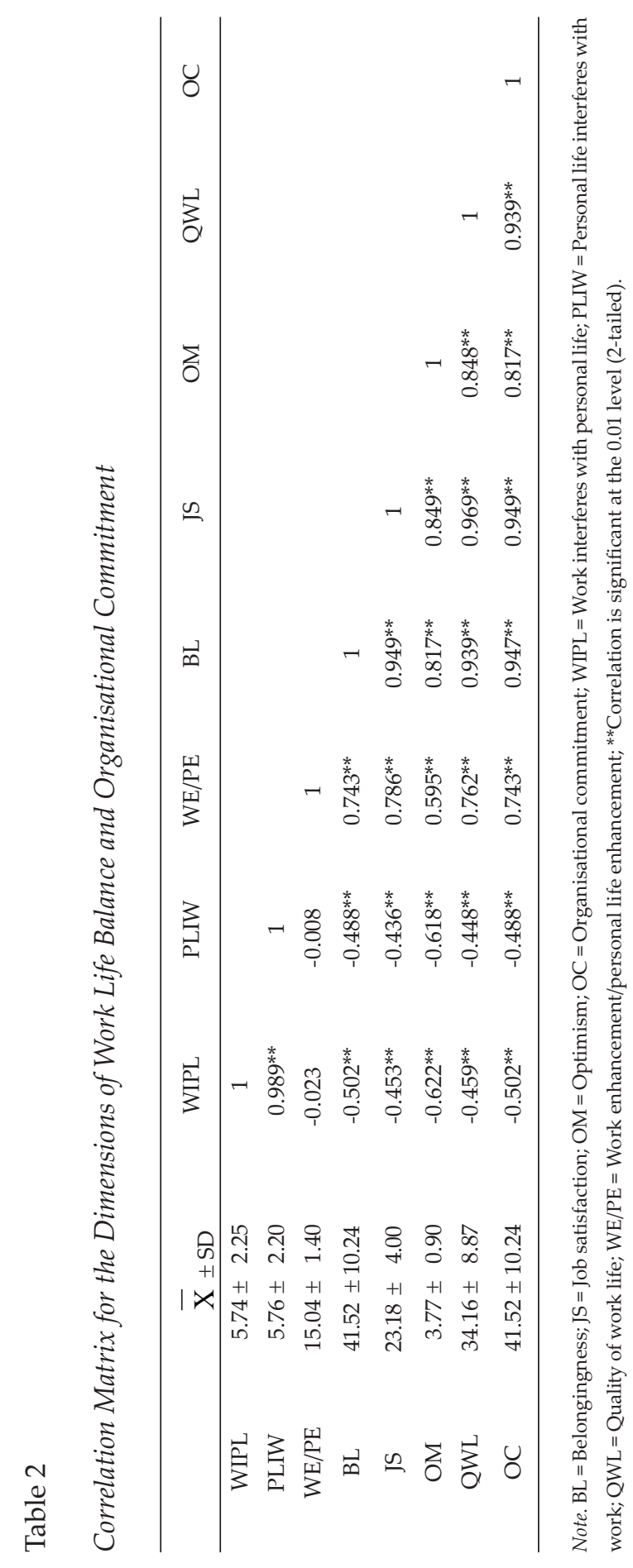

IJMS 17 (1), 129-147 (2010) 137 


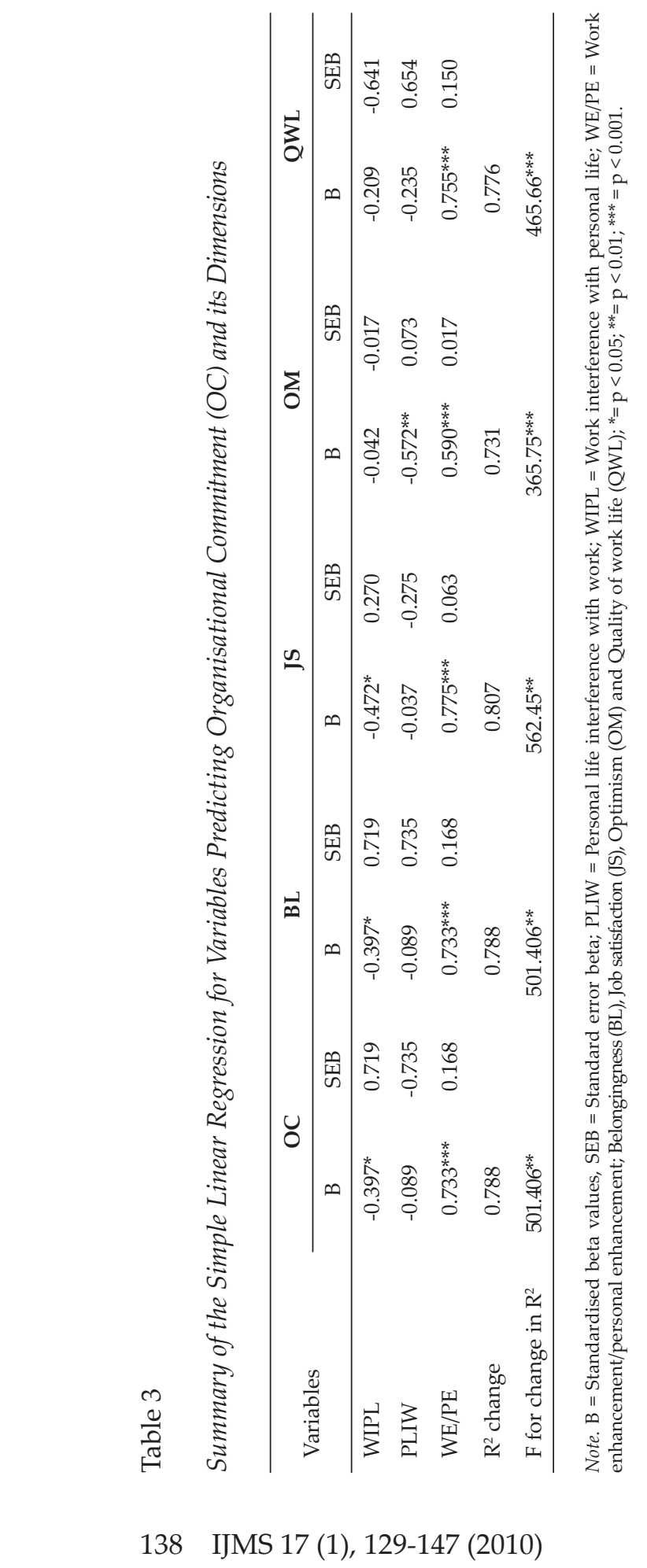




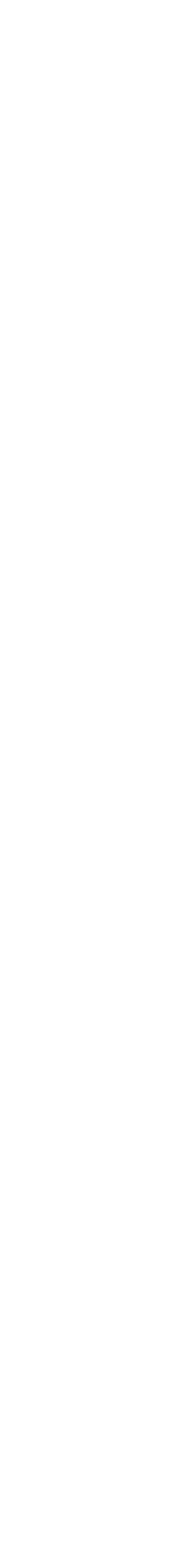

Regression analysis was used to find out the strength of association between a set of predictor variables (WIPL, PLIW, and WE/PE) and OC along with its dimensions (Table 3 ). WIPL was a significant $(\mathrm{p}<0.05)$ negative predictor of OC $(\beta=-0.397)$ and its dimensions (Table 3). It may be noted that optimism and QWL, even though negatively supported WIPL, were statistically insignificant. This showed that WIPL had $78.7 \%$ of variance (adjusted $\mathrm{R}^{2}=0.787$, $\mathrm{F}=501.406, \mathrm{p}<0.05$ ) with OC (Table 3). Hence $\mathrm{H}_{1}$, which stated that WIPL has a negative effect on $\mathrm{OC}$ and its dimensions, received partial support (Table 3). However PLIW had no significant effect on OC and most of its dimensions (Table 3). Therefore $\mathrm{H}_{2}$, which stated that personal life interference with work has a negative effect on organisational commitment and its dimensions, did not receive any support except for optimism (Table 3$)$. WE/PE $(\beta=0.733)$ was the only significant $(\mathrm{p}<0.001)$ positive predictor of $\mathrm{OC}$ and its dimensions (Table 3). This accounted for $78.7 \%$ of variance (adjusted $\mathrm{R}^{2}=0.787, \mathrm{~F}=$ 501.406, $\mathrm{p}<0.001$ ). Hence the data supported $\mathrm{H}_{3^{\prime}}$ which stated that WE/PE would have a positive effect on OC and its dimensions.

\section{Discussion}

The present study examined the relationship of the various dimensions of work-life balance with $\mathrm{OC}$ and its dimensions. Correlation matrix (Table 2) shows the associations of WIPL, PLIW, and WE/PE with OC and its dimensions. The results of this study provided several insights into the important contributions of work and family domains to organizational commitment. From the regression analysis (Table 3), it is clear that WE/PE is an essential factor to achieve a high organisational commitment among employees. WE/PE strongly and positively predicted its association with $\mathrm{OC}$ and its dimensions indicating that WE/PE will increase OC of employees (Tables 2, 3). Both work and family domains are expected to provide individuals with resources such as enhanced esteem, income, and other benefits that help the individuals to present better performances across the other domains (Friedman \& Greenhaus, 2000; Barnett \& Hyde, 2001) and such a conducive environment would create a positive emotional attachment to the organisation. In the present study, WE/PE is strongly correlated with the feeling of belongingness to the organisation, which would lead to organisational citizenship, thus resulting in increased OC. According to Gbadamosi (2003), enhancements in the work life and personal life will improve the employee's attitudes such as a strong belief in and acceptance of organisational goals and values, and a willingness to exert considerable effort on behalf of the organisation. In the light of this report, it is vivid that enhancement in both the domains improves the affective attachment of the employee toward the organisation and thereby increase the OC. On the other

IJMS 17 (1), 129-147 (2010) 
hand, OC enhances performance and organisational effectiveness because employees who feel comfortable in their personal roles and competent in their jobs reportedly express greater attachment to their organisation (Allen \& Meyer, 1990). Mathieu and Zajac (1990) have also opined that enhanced job characteristics, particularly when taken as an aggregate, offer promise to the development of OC. This observation is again supported by the report of Meyer, Allen, and Topolnytsky (1998), that employee's behaviour at work and their commitment to the organisation are influenced not only by the work enhancement alone but also by the personal enhancement.

단

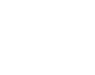

$(1)$

The present study also suggested that WE/PE is strongly and positively related to job satisfaction. This implies that the various organisational and personal factors that enrich the work as well as personal life could increase the individuals' commitment levels to the organisation through affective job satisfaction. This observation is in agreement with the report of Namasivayam and Zao (2007) that individuals who express greater commitment to an organisation are not likely to reduce their levels of job satisfaction even in stressful condictions.

Loyalty is a product of QWL and optimism. Therefore an increase in QWL and optimism would increase the loyalty of the employees towards the organisation leading to increase in OC. While optimism refers to an employee's positive thinking toward his/her work and organisation, QWL is viewed as an alternative to the control approach of managing people. QWL approach considers people as an asset to the organisation, rather than as costs and in this context; people perform better when they are allowed to participate in managing their work and decision-making. This approach motivates people by satisfying not only their economic needs but also their social and psychological needs. To satisfy the new generation work force, organisations need to concentrate on job designs and work culture because today's work force is also realising the importance of relationships and is trying to strike a balance between career and personal lives. The present study also strongly predicts the positive influence of WE/PE on optimism and QWL of employees, which in turn could enhance OC.

Furthermore, in a situation of increased WE/PE, the employees would benefit in both the domains and according to Ghai (2007), good QWL generates an atmosphere of good interpersonal relations and highly motivated employees. Such a conducive organisational atmosphere ensures high QWL and optimism, which in turn could lead to more empowerment in their personal life as well as OC. Our findings are also in agreement with the report of Greenblatt (2002) that enhancement in the personal domain by means of physical, psychological, emotional, and social resources could directly increase one's ability to perform at home and at work. This can lead to 


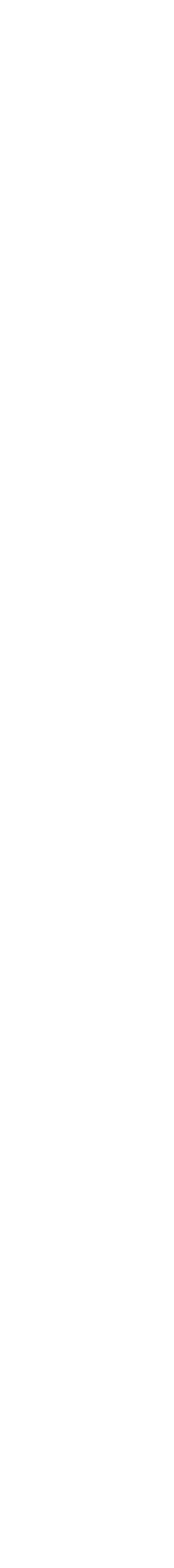

improved work life balance of the individual, which according to the present study exerts strong positive influence on the dimensions of OC, such as belongingness, job-satisfaction, optimism, and QWL.

Employees are regarded as committed to the organisation if they willingly continue their association with the organisation and undertake considerable effort to achieve organisational goals. Such behaviour from the employees is the manifestation of their work life balance, which contributes to the enhancement in the work as well as personal domains. On the contrary, situations of work-life imbalances, where work interferes with family domain or personal life interferes with work domain are characterised by the development of negative work attitudes such as non-commitment to the organisation, job dissatisfaction, and so forth. In fact, work family balance reflects an individual's orientation toward different roles, which according to Marks and McDermid (1996) could be considered as an inter-role phenomenon. Therefore, in order to have a balanced orientation to multiple roles, individuals should exercise equally positive commitments to different life roles.

The relationship between antecedents and consequences of $\mathrm{OC}$ has been reported by various authors (Mathieu \& Zajac, 1990; Vandenberg \& Lance, 1992; Carmeli \& Freund, 2004). In the present study, work life balance is considered as an antecedent of organisational commitment. However, the various facets of work life balance (WIPL, PLIW, and WE/PE) do not have the same trend of relationship with OC. A critical assessment of the results of the present study revealed that while WIPL exerts a significant negative impact on OC, WE/PE is having significant positive impact (Table 3). On the other hand, even though PLIW exerts a negative impact; it is not significant (Table 3). These observations are in agreement with the reports that conflicts due to work and family role interferences reduce organisational commitment (Wallace, 1995; Kossek \& Ozeki, 1998). That means, by reducing the conflicts arising due to the mutual interference of work and family roles (especially WIPL), OC of the employees can be enhanced because in such situations employees are at a better position to discharge their family responsibilities also. Moreover, conflict between work and family occurs when individuals have to perform multiple roles (for example; worker, spouse, parent, and so forth) simultaneously (Greenhaus \& Beutell, 1985) because each of these duties requires time, energy, and specific personal roles such as attention, involvement, and so forth, for successful culmination. Therefore, WIPL driven conflicts would naturally drain away resources from the personal / family dimensions leading to unsolicited or negative relationship with the various dimensions of OC. Grandey, Cordeiro, and Crouter (2005) also viewed that individuals develop work attitudes such as OC and job satisfaction using information about the extent that job interferes with other valued roles.

IJMS 17 (1), 129-147 (2010) 
With respect to the act of balancing the inter-domain struggles between work and family, WIPL is found to be a unique negative predictor of OC. Various works have also explored the influence of work family conflict on work life balance and favoured the idea that the inter domain struggle usually leads to a number of negative attitudes and consequences including decreased job satisfaction (Netmeyer, Boles \& McMurrian 1996; Kossek \& Ozeki, 1998; Boles, Howard \& Donofrino, 2001; Boyar, Macrtz, Pearson, \& Keough, 2003). The present study clearly suggested that the interplay between work and family domains directly influences the OC. Namasivayam and Zao (2007) reported that in the case of family interference with work, feeling of belongingness toward the organisation could moderate the effects of work family conflicts on job satisfaction. But the regression analysis (Table 3) of the present study showed no significant impact of PLIW neither on belongingness nor job satisfaction. However, it predicts a significant negative impact on optimism of employees. This may be due to the fact that the employees find it increasingly difficult to give due justice to their work role. This could lead to erosion in their positive thinking and self esteem.

Optimism is the strong belief in and acceptance of organisational goals and values in a positive way. According to Yousef (2001), optimism is strongly related to attitudes toward work, desire for upward career mobility, attitude toward rewards and degree of job involvement. On the basis of this report, a negative significant impact of PLIW and optimism of employees as observed in the present study could probably indicate the crippling of the work domain both physically as well as mentally. However, as the work domain is less permeable than the family domain (Frone et al., 1992; Eagle, Miles \& Icenogle 1997), work is more likely to impact family than vice versa.

In the light of the findings of present investigation, it may be concluded that conflicts between the work and family domains play pivotal roles in determining the OC of employees. However, it should also be mentioned that in addition to the parameters analysed in the present study, employee commitment is also influenced by a variety of other factors. These factors include characteristics of the job, work environment, interpersonal relationship, compensations, etc. (Namasivayam \& Zao, 2007) and more particularly individual's work ethics and values. As suggested by Yousef (2001), individuals who prefer positive work ethics are likely to be more committed to the organisation.

\section{Managerial Implications}

Our results suggested that employees who are not able to maintain a balanced relationship within and between work and family domains have

142 IJMS 17 (1), 129-147 (2010) 


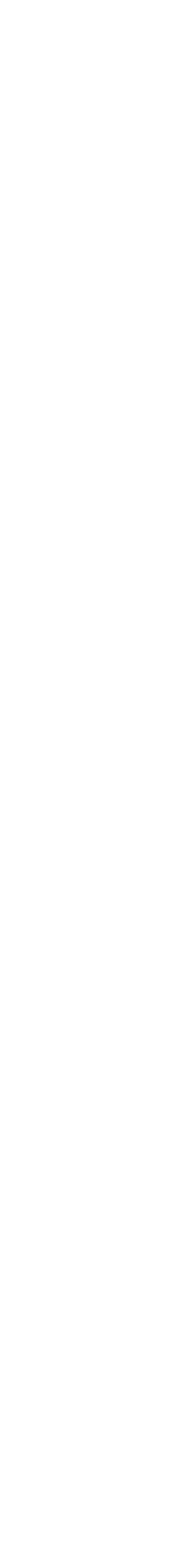

low $\mathrm{OC}$, and it is a difficult challenge for human resource managers as well as the employees themselves. It is also clear from the study that WE/PE has a direct and significant positive impact on employees' OC. In this situation, any organisational support to increase WE/PE would help strengthen work as well as life domains of employees, and that in turn would increase OC. A higher level of OC naturally helps in attaining a high degree of employee loyalty toward the organisation. Therefore, it is strongly suggested that organisations should implement work life balance programmes such as flextime, compressed work week, job sharing, telecommuting, child and elder care benefits, and so forth, wherever possible in order to reduce the work-life imbalance. As far as the human resource management in the service sector is concerned, within the framework of the present study, WIPL and WE/PE are important antecedents of organisational commitment. While WE/PE are positive predictors of OC, WIPL is a significant negative predictor providing scope for further theoretical development. Therefore human resource personnels in service sector organisations can make use of these findings to design organisational policies. Finally, work-family imbalance should not be considered merely as an individual/family issue. Rather, it can have wide ramifications in the organisation as well as in the society.

\section{Conclusion}

The changing employment scenario in the service sector of India has given rise to problems of work-life balance. The impacts of such problems are reflected in the organisational as well as personal lives of the employees. In the organisational sector, the present study has revealed a decreasing trend of organisational commitment along with the increase in the worklife imbalance. This is mainly because the employees have to perform different roles in their life namely; spouse, parent, daughter, son, employee, and so forth. Furthermore, each of these roles requires time and energy for performing them satisfactorily. However the incompatible role competition and their infringement on each others borders makes it difficult for the employees to give due justice to their organisational and family roles leading to decreased organisational commitment.

\section{References}

Allen, N.J., \& Meyer, J.P. (1990). The measurements and antecedents of affective, continuance and normative commitment to the organisation. Journal of Occupational Psychology, 63, 1-18.

Aryee, S., Srinivas, E.S., \& Tan, H.H. (2005). Rhyms of life: Antecedents and outcomes of work family balance in employed parents. Journal of Applied Psychology, 90(1), 132-146.

IJMS 17 (1), 129-147 (2010) 
Barnett, R.C., \& Hyde, J.S. (2001). Women, work and family: An expansionist theory. American Psychologist, 56, 781-796.

Becker, G.S. (1985). Human capital, effort and sexual division of labour. Journal of Labour Economics, 3, 35-58.

Becker, G.S. (1991). A treatise on the family. Cambridge, MA: Hardward University Press.

Boles, J.S., Howard, W.G., \& Donofrio, H.H. (2001). An investigation into the interrelationships of work family conflict, family-work conflict and work satisfaction. Journal of Managerial Issues, 13(3), 376-390.

Boyar, S.L., Macrtz, C.P. Jr. Pearson, A.W., \& Keough, S. (2003). Work family conflict: A model linkages between work and family domain variables and turnover intentions. Journal of Managerial Issues, 15, 175-190.

Carmeli, A., \& Freund, A. (2004). Work commitment, job satisfaction and job performance: An empirical investigation. International Journal of Organisation Theory and Behaviour, 7, 289-309.

Danes, S.M. (1998). Multiple roles, balance between work and leisure and satisfaction with level of living. Family and Consumer Sciences Research, 26(4), 401-416.

Duncan, S.F., \& Goddard, H.W. (1993). Stressors and enhancers in the marital/family life of family professionals and their spouses. Family Relations, 42, 434-441.

Eagle, B.W., Miles, E.W., \& Icenogle, M.L. (1997). Inter role conflicts and the permeability of work and family domains: Are there gender differences? Journal of Vocational Behaviour, 50, 168-184.

Fisher, G. (2001). Work/personal life balance: A construct development study (Unpublished Doctoral dissertation). Bowling Green State University Bowling Green, Ohio, USA.

Friedman, S.D., \& Greenhaus, J.H. (2000). Work and family-allies or enemies? What happens when business professionals confront life choices. New York: Oxford University Press.

Frone, M.R., Russel, M., \& Cooper, M.L. (1992). Antecedents and outcomes of work-family conflict: Testing a model of the work family interface. Journal of Applied Psychology, 77, 65-78.

Gbadamosi, G. (2003). HRM and the commitment rhetoric: Challenges for Africa. Management Decisions, 41, 274-280.

Ghai, R.K. (2007). Quality of work life in J.K. Tyre: An empirical analysis. Annamalai Journal of Management, February 17-21.

Grandey, A.A., Cordeiro, B.L., \& Crouter, A.C. (2005). A longitudinal and multisource test of work family conflict and job satisfaction relationship. Journal of Occupational and Organisational Psychology, 78, 305-323.

Greenblatt, E. (2002). Work/life balance: Wisdom or whining. Organisational Dynamics, 31(2), 177-193.

144 IJMS 17 (1), 129-147 (2010) 
Greenhaus, J.H., \& Beutell, N.J. (1985). Sources of conflict between work and family roles. Academy of Management Review, 10(1), 76-88.

Greenhaus, J.H., \& Powell, G.H. (2006). When work and family are allies: A theory of work family enrichment. Academy of Management Review, 31(1), 72-92.

Greesa, A.L., Wellmana, J.A., \& Laissiterb, G.D. (2009). Dispositional optimism and engagement: The moderating influence of goal prioritization. Journal of Personality and Social Psychology, 96, 913-932.

Gudmundson, A.J. (2003). Balancing work and family: Perspective of Australian dual-earner parents (Unpublished doctoral dissertation). School of Applied Psychology, Griffith University, Australia.

Gutek, B.A., Searle, S., \& Kepa, L. (1991). Rational versus role explanations for work family conflict. Journal of Applied Psychology, 76, 560-568.

Hartog, N.D., Hoogh, A.H.B., \& Keegan, A.E. (2007). The interactive effects of belongingness and Charisma on helping and compliance. Journal of Applied Psychology, 92, 1131-1139.

Harvey, M.G. (1985). The executive family: An overlooked variable in international assignments. Columbia Journal of World Business, 20, 8493.

Haung, Y-H., Hammer, L.B., Neal, M.B., \& Perrin, N.A. (2004). The relationship between work to family conflict: A longitudinal study. Journal of Family and Economic Issues, 25, 79-100.

Hyde, A.M., \& Roy, R. (2006). Organisational commitment scale. Agra, India: National Psychological Corporation.

Jones, T.L., \& Lathlean, J. (2008). Belongingness: A pre requisite for nursing student's clinical learning. Nurse Education and Practice, 8, 103-111.

Karatepe, O.M., \& Killic, H. (2007). Relationship of supervisor support and conflicts in the work-family interface with the selected job outcomes of frontline employees. Tourism Management, 28, 238-252.

Katz, D., \& Kahn, R.L. (1978). The social psychology of organisations (2nd ed.). New York: Wiley.

Katzella, R.A. (1983). Improving quality of work life. American Psychologist, 38, 126.

Kinnier, R.T., Katz, E.C., \& Berry, M.A. (1991). Successful resolution to the career versus family conflict. Journal of Counselling and Development, $69,439-444$.

Kossek, \& Ozeki, C. (1998). Work family conflict policies and job life satisfaction relationship: A review and directions for organisational behaviour-human resources research. Journal of Applied Psychology, 83(2), 139-149.

Lawlera, E.E. (1982). Strategies for improving quality of work life. American Psychologist, 37, 486-493. 
Lok, P., \& Crawford, J. (2004). The effect of organisational culture and leadership style on job satisfaction and organisational commitment. Journal of Management Development, 23, 321-338.

Marks, S.R., \& McDermid, S.M. (1996). Multiple roles and the self: A theory of role balance. Journal of Marriage and the Family, 61, 476-490.

Mathieu, J.E., \& Zajac, D.M. (1990). A review and meta-analysis of the antecedents, correlates and consequence of organisational commitment. Psychological Bulletin, 108, 171-194.

Mayer, J.P., \& Allen, N.J. (1984). Testing the side-bet theory of organisational commitment: Some methodological considerations. Journal of Applied Psychology, 69, 372-378.

Meyer, J.P., Allen, N.J., \& Topolnytsky, L. (1998). Commitment in a changing world of work. Canadian Psychology, 39, 82-97.

Mowday, R.T., Porter, L.M., \& Steers, R.M. (1982). Employee organisational linkages: The psychology of commitment, Absenteeism and Turnover, New York: Academic Press.

Namasivayam, K., \& Mount, D.J. (2004). The relationship of work family conflicts and family-work conflict to job satisfaction. Journal of Hospitality and Tourism, 28, 242-250.

Namasivayam, K., \& Zao, X. (2007). An investigation of the moderating effects of organisational commitment on the relationships between work family conflict and job satisfaction among hospitality employees in India. Tourism Management, 28, 1212-1223.

Nauman, E. (1993). Antecedents and consequences of satisfaction among expatriate managers. Group and Organisational management, 18, 153187.

Netmeyer, R.G., Boles, J.S., \& McMurrian, R. (1996). Development and validation of work family conflict and family-work conflict scales. Journal of Applied Psychology, 81, 400-410.

Payton-Miyazaki, M., \& Brayfield, A.H. (1976). The good job and the good life: Retention of characteristics of employment to general well being. In. A.D. Biderman \& T.F. Drusy (Eds.), Measuring Work Quality for Social Reporting, (10-5-150), Beverly Hills: Sage.

Poster, W.R., \& Prasad, S. (2003). Work family relations in transnational perspective: A view from high-tech firms in India and United States. Social Problems, 52, 122-146.

Rice, R.W., Near, J.P., \& Hunt, R.G. (1980). The job satisfaction/life satisfaction relationship: A review of empirical research. Basic and Applied Social Psychology, 1, 37-64.

Segerstrom, S.C., \& Nes, L.S. (2006). When goals conflict but people prosper: The case of dispositional optimism. Journal of Research in Personality, 40, 675-693.

Shaffer, M.A., Harrison, D.A., Gilley, K.M., \& Luk, D.M. (2001). Struggling for balance amid turbulence on international assignments: Workfamily conflict, support and commitment. Journal of Management, 27, 99-121. 
Shah, H., \& Agarwal, S.P (2008). Educating India, Education Sector Report. Mumbai, India: Publisher Angel Broking pp. 84.

Sieber, S.D. (1974). Toward a theory of role accumulation. American Sociological Review, 39, 567-568.

Taylor, M.S., Audia, G., \& Gupta, A.K. (1996). The effect of lengthening job tenure on managers' organisational commitment and turnover. Organization Science, 7, 632-648.

Tett, R.P., \& Meyer, J.P. (1993). Job satisfaction, organisational commitment, turnover intention: Path analysis based on meta-analytic findings. Personal Psychology, 46, 259-293.

Vandenberg, R.J., \& Lance, C.E. (1992). Examining the causal order of job satisfaction and organizational commitment. Journal of Management, $18,153-167$.

Wallace, J.E. (1995). Organisational and professional commitment in professional and non-professional organisations. Administrative Science Quarterly, 40, 228-225.

Wayne, J.H., Mussica, N., \& Fleeson, W. (2002). Considering the role of personality in the work family experience: Relationships of the big five to work family conflict and facilitation. Journal of Vocational Behaviour, 64, 108-130.

Wright, T.A., \& Corpanzano, R. (2007). Happy productive worker thesis revisited. Research in Personal Human Resource Management, 26, 269307.

Yousef, D.A. (2001). Islamic work ethics: A moderator between organisational commitment and job satisfaction in cross cultural context. Personnel Review, 30, 152-165.

Zedeck, S. (1992). Exploring the domain of work and family concerns: In S. Zedeck (Ed.), Work, families, and organisations, (476) San Francisco: Jossey-Bass. 